\title{
Agent based interaction of commodity price and freight market
}

\section{Emtia fiyatı ve navlun piyasasının ajan bazlı etkileşimi}

\author{
${ }^{1}$ Res. Asst. Dr., Dokuz Eylül University, \\ Maritime Faculty, İzmir, Turkey \\ abdullah.acik@deu.edu.tr, \\ ORCID: 0000-0003-4542-9831 \\ 2 Prof. Dr., Dokuz Eylül University, \\ Maritime Faculty, İzmir, Turkey \\ ozlen.baser@deu.edu.tr \\ ORCID: 0000-0001-6632-2617
}

\section{Corresponding Author:}

Abdullah Açık,

Dokuz Eylül University, Maritime Faculty, İzmir, Turkey abdullah.acik@deu.edu.tr,

Submitted: $20 / 11 / 2020$

Revised: 25/12/2020

Accepted: 30/12/2020

Online Published: 25/03/2021

Citation: Açık, A., \& Başer, S.Ö., Agent based interaction of commodity price and freight market, bmij (2021) 9 (1):56-75, doi: https://doi.org/10.15295/bmij.v9i1.1684

\author{
Abdullah Açık ${ }^{1}$ \\ Sadık Özlen Başer²
}

\begin{abstract}
This study investigates the relationship between iron ore, coal and wheat prices, three major dry bulk cargoes, and Capesize, Panamax, and Handymax freight, which are the intensively used ships in transportation three essential cargoes. These major ship types are considered agents in the market. The main research questions are whether there are a volatility spillover and risk transmission between commodity prices and freight routes and whether there is a differentiation in relations according to the type of cargo and intensive carriage rate. Causality in variance analysis is used to test these research questions, which determines the flow of information between variables and the volatility spillover. The obtained results reveal that the interaction can differ according to both ship types and commodity types, and volatility spillovers and risk transfers are from commodity prices to freight rates.
\end{abstract}

Keywords: Commodity Price, Freight Market, Volatility Spillover

Jel Codes: M310, L25, K65

Öz

Bu çalışmanın amacı, 3 ana kuru dökme yük olan demir cevheri, kömür ve buğday fiyatları ile bu üc temel yükün taşınmasında yoğun olarak kullanılan gemiler olan Capesize, Panamax ve Handymax navlunları arasındaki ilişkiyi araştırmaktır. Bu başlıca gemi türleri, piyasadaki ajanlar olarak ele alınmışlardır. Temel araştırma soruları, emtia fiyatları ve navlun rotaları arasında bir oynaklık yayılımı ve risk transferi olup olmadığı ve yük türü ve yoğun taşıma oranına göre ilişkilerde bir farklılaşma olup olmadığıdır. Bu araştırma sorularını test etmek için, değişkenler arasındaki bilgi akışını ve oynaklık yayılımını inceleyen varyansta nedensellik analizi kullanılmıştır. Elde edilen sonuçlar, etkileşimin hem gemi türlerine hem de emtia türlerine göre farklılık gösterebildiğini ve oynaklık yayılımı ve risk transferlerinin emtia fiyatlarından navlun oranlarına doğru olduğunu ortaya koymaktadır.

Anahtar Kelimeler: Emtia Fiyatı, Navlun Piyasası, Oynaklık Yayılımı

JEL Kodları: Q02, R41 


\section{Introduction}

Maritime markets and especially freight markets are defined as risky markets due to high volatility. Since they have a derived demand structure, they can be immediately affected by shocks in the world economy. Non-trend expansion or contraction in production activities cause high volatility in the maritime market. The main reason for this is that the supply curve is inelastic in the short run in the maritime market. The time-to-build effect lies behind this structure. The ship order placed in line with the future expectations arising according to the current market conditions can contribute to its carrying capacity by entering the market only between 1-3 years. Therefore, when the order is placed today, it remains uncertain how the market will be when the ship is completed.

Although order quantities can be tracked through shipyards, demand for shipping services is difficult to predict. In the world economy, political balances, crises, and wars between countries are felt immediately in the maritime markets. In particular, the impact of the 2008 crisis on the maritime industry was very high. Demand for raw materials increased significantly, mainly due to the China boom's impact before the crisis. This increase in demand has caused historical increases in shipping freight rates. However, due to the global economic crisis, there was a shrinkage in demand; in addition to this, a high supply increased with the ship's entry into the buoyant shipping period before the crisis. As a result, freight rates have dropped dramatically. Besides, debt crises such as the Eurozone have negatively impacted the maritime market, which has a derived demand structure, as they led to contractions in international trade. In more recent times, trade wars between central states have negatively affected international trade. Due to the derived demand structure, shipping has been hit hard by this decrease in trade volumes. The Baltic Capesize Index fell to negative values for the first time in index history. Natural events of different sizes also affect the maritime market by rendering the ports dysfunctional and causing commercial routes.

Due to its market structure, several researchers define the dry bulk market as a perfect competition market (Harlaftis and Theotokas, 2002), leading to high competition in the market. Although some vessels specialise in carrying some special cargoes, cargo pass-through between vessels is relatively easy under favourable market conditions. For instance, considering the economics of scale reality, although iron ore cargoes' transportation cost on long routes is high with Panamax type vessel, iron ore cargoes transfer from Capesize type ships to Panamax type ships during the periods when the freights exceed a specific high bar. When such a level is reached, it becomes economical to carry the iron ore cargo for Panamax type ship owners and prefer this ship type for shippers. Of course, in such a case, the situation in the markets where Panamax type ships are mostly preferred is practical and determines the available tonnage.

The commodities, which consist of three main bulks discussed in the study, differ in production structures, supply structures, and demand structures. While iron ore and coal are mostly defined as industrial products, and their production processes depend on underground activities, wheat plays a significant role in household consumption, and the production process is primarily dependent on climatic factors. Also, since these cargoes' parcel size distribution functions are different, various types of ships are specialised in the transportation of these cargoes. However, depending on the market conditions, there may also be cargo pass-through between ship types. Demand for these commodities also affects maritime demand and causes fluctuations in the maritime markets, especially in the freight market. Considering that commodities' prices also carry information about their supply and demand, there may be an interaction between commodity prices and freight markets. This possible interaction has also been studied in the maritime economics literature, and significant results have been achieved (Kavussanos et al., 2010; Kavussanos et al., 2014; Chou et al., 2015; Tsioumas and Papadimitriou, 2018; Açık and Başer, 2018a; Açık and Başer, 2018b; Açık and İnce, 2019; Açık and Başer, 2019; Başer and Açık, 2019; Açık and Başer, 2020; Angelopoulos et al., 2020). In these studies, interactions in derivative markets and over past prices were examined. This thesis aims to test the relationships over the prices that have already taken place rather than the analysis made on the future prices shaped by the expectations. It differs from studies conducted in this direction using a more up-to-date method and 
approaching the subject from a non-linear perspective. Also, considering that reacting to new information is faster, spot freight rates were used in this study.

This study is based on three research questions; (i) Is there any volatility spillover and risk transfer from commodity prices to the freight market? (ii) Is the flow of information from the prices of commodities to freights of the most used ships unidirectional? (iii) Is there a difference in terms of information flow between commodity price and freight by type of commodity?

Why are these questions important? As Kavussanos et al. (2010) express, any information that enables early discovery of the change in freight rates increases investment decisions' accuracy. Given the very volatile nature of the maritime market and the market cycles of different sizes and lengths, this is vital for both ship and cargo owners. For instance, carrying the 200,000 tons of iron ore cargo to $\$ 2$ less or more per ton can result in a $\$ 400,000$ change in revenue for the shipowner at once. Alternatively, in terms of cargo owner, there is a huge transportation cost. At this point, considering that each type of ship usually specialises in the transportation of different types of cargoes, each ship can be identified as an "agent" in the market. In this respect, each cargo type's effects on the type of ship may differ, and each ship owner (agent) may have to follow a different strategy according to the cargo type. Besides, a single agent may be affected by different commodity prices, as there is a pass-through between different types of cargoes among the ships. In this respect, this thesis aims to determine whether there is a spillover and risk transmission between commodity prices and freight rates, if any between which types of ships and cargoes, and whether specialisation in a cargo type composes a differentiation in the relationship. Thus, it aims to understand each shipowner's market better and reduce the risks arising from uncertainty by revealing agent-based findings.

In the following section, we evaluate vessel specialisation in dry bulk shipping, as different ship types are included in our research. Then we compile the studies examining the commodity and maritime markets relationships in the literature to draw the framework of the study. The method used in the study is introduced in the fourth section, and the dataset used in the analysis is investigated in the fifth section. After the results obtained from the analyses are presented and discussed in the sixth section, the conclusions are made in the last section.

\section{Vessel Specialisation in Dry Bulk Shipping}

Ships have significant advantages for the sustainable run of world trade. Also, having a cost-free infrastructure for transport activities, which is the sea, provides an essential advantage to ships (ECMT, 2001:44). This transport service is provided by ship investors who have positive prospects for the future using significant capital investments. Which type of ship will be preferred for these ship owners requires a critical and systematic strategy since the ships are expensive investments that have been in service for many years. A wrong strategy may have a high cost to the investor. These investments should be made considering some critical factors in order to be able to survive in the competitive world (Bendall and Stent, 2005:13).

Stopford (2009:567) defines these factors as cargo type, type of shipping operation, and commercial philosophy. The shipowner must decide what type of cargo it targets because some cargoes can only be transported with a single ship type, while some cargoes can be transported with different ships. In some cases, the ship's physical properties may restrict cargo choice; for example, the hatch type and size of the dry bulk ship may cause problems for some vast general cargoes' transportation. The owner must decide how he wants to use his ship commercially. It may charter long term or run on the spot market. Accordingly, a ship type should be selected to meet the expectations of the targeted market. For purely commercial reasons/ purposes, the owner may choose a flexible ship that can carry different cargo types or a specialised ship for a particular cargo. In this case, the transportation costs of flexible ships per unit will be high, while special ships' transportation costs will be low. However, although this generates a cost advantage for the specialised ship, it reduces the chance of finding cargo. Therefore, ship selection is a crucial decision for the owner to continue his commercial activities. 
Considering the factors related to the ship selection, a dry bulk cargo fleet has been formed as a result of cumulative investments made by shipowners to be used in commodity transportation. The dry bulk cargo fleet accounts for $42.6 \%$ of the total world fleet's transport capacity in 2019, making the dry bulk market an important position in the world maritime trade (UNCTAD, 2019). Vessel types in the dry bulk shipping market are classified based on their sizes as Handysize (20,000-35,000 DWT), Handymax (35,000-45,000 DWT), Supramax (45,000-55,000), Panamax (60,000-75,000 DWT) and Capesize (80,000300,000 DWT) respectively (Alizadeh and Nomikos, 2009: 30).

In dry bulk cargo transportation, specialised ship types have been formed on certain cargoes. The Parcel Size Distribution function mentioned in the following sections can also explain the selection of these ships. Table 1 shows the approximate transport shares of the three major bulk cargoes. Capesize type vessels are specialised in iron ore transportation, and so they carry approximately $70 \%-80 \%$ of the world's iron ore cargo. Panamax type vessels are commonly used in Coal (40\%-50\%) and Grain (40\%$50 \%$ ) cargoes, while Handymax type vessels are primarily used in grain (45\%-55\%) transportation (Chen et al., 2014).

Table 1. Three Types of Main Cargoes of Three Main Bulk Carriers

\begin{tabular}{|l|c|c|c|}
\hline & Iron Ore & Coal & Grain \\
\hline Capesize & $70 \%-80 \%$ & $30 \%-40 \%$ & $0 \%-5 \%$ \\
\hline Panamax & $10 \%-20 \%$ & $40 \%-50 \%$ & $40 \%-50 \%$ \\
\hline Handymax & $10 \%$ & $10 \% 20 \%$ & $45 \%-55 \%$ \\
\hline
\end{tabular}

Source: Chen et al. (2014)

\section{Literature Review}

The literature studies can be categorised as follows; reviewing the relationship between commodity and freight prices; reviewing the relationship between commodity and freight derivative markets; reviewing the relationship between commodity price and second-hand ship value; and other commodity-related studies. In general, when the studies between commodity prices and maritime markets are analysed, it is seen that significant results were obtained even though there is not rich literature on this subject.

\section{Commodity and Freight Markets}

Almost all of the cargoes carried by dry bulk transportation are industrial products, and they are used as raw materials to produce several materials. As mentioned earlier, some ships are specialised in the transportation of some cargoes. Capesize ships are among these ships; approximately $70-80 \%$ of the iron ore transported in the World is carried by Capesize ships. A large part of the iron ore transported is also used in steel manufacturing. It is, therefore, likely that there is an interaction between steel prices and Capesize freights. Based on this research question, the relationship between the Baltic Capesize Index (BCI) and Asian Steel Index (ASI) was tested in a study conducted by Chou et al. (2015). The authors used a weekly dataset covering the periods from July 2007 to December 2011 and employed the VARMA method. As a result of the research, it was concluded that the ASI variable is two periods ahead of the $\mathrm{BCI}$ variable, and thus the BCI variable is the leading indicator for the ASI variable. In this case, it can be said that shipping costs are an essential factor in indirectly determining commodity demand by affecting the final steel prices.

Dry bulk transportation is used to transport many cargoes, but some cargoes' transportation rates are relatively high compared to other cargoes. Therefore, this cargo group is defined by many researchers as major bulks. In this context, based on the idea that the changes in the prices of these main cargoes affect the freight level of types of ships they are transported, Tsioumas and Papadimitriou (2018) examined the relationship between commodity and freight levels of the vessels that correspond to primarily used in the transport of this commodity. The authors used the Baltic Capesize Index (BCI) and the Baltic Panamax Index (BPI) as the freight levels' representatives and employed Granger 
causality and co-integration methods. The authors found a bidirectional causality relationship between the $\mathrm{BCI}$ index and iron ore and coal prices. It also identified a one-way causality relationship between wheat and BPI, from commodity to freight. The author states that sudden increases in commodity prices may throw freight for a short period, but high commodity prices may adversely affect trade in the long run.

In another study, Açık and Başer (2019) examined the relationship between commodity prices and freight rate by considering the possible impact of the 2008 crisis. In addition to the contraction in demand in these years, new ship orders, which had increased excessively, were also helpful in the dry bulk shipping crisis. Since the freight revenues had reached incredible levels, the lag in ship delivery due to the construction process (Başer and Açık, 2018) has led to an uncontrollable supply side increase. In this respect, the study was conducted to examine whether the effect of commodity prices on the freight market differed before and after the 2008 crisis. Two hundred thirty-three monthly observations covering the period between January 2000 and June 2019 were used, and asymmetric causality analyses were applied. Freight rate is represented by the price of transport per tonne from Tubarau (Brazil) to Qingdao (China) via Capesize vessel, and the general price published by Worldbank represents the iron ore price. A significant break in level and trend was detected in July 2008 by unit root tests with a single structural break (Zivot and Andrews, 1992; Lee and Strazicich, 2013), and the sample was divided into pre-crisis and post-crisis periods. There was an increasing trend before the crisis and a decreasing trend after the crisis. In the pre-crisis period, it was determined that positive shocks in the iron ore prices are the causes of positive shocks in the freight rates. In the post-crisis period, adverse shocks in the ore prices were found to be the causes of the adverse shocks in the freight rates, and negative shocks were found to be the causes of the positive shocks. The study's findings revealed that the impact of commodity prices on the Capesize freight market might change before and after the crisis.

A study conducted by Açık and İnce (2019) examined the relationship between the freight rates of the three major ship types in the bulk market and the three major bulk cargoes' prices. These three types of ships consist of Capesize, Panamax, and Handymax vessels, while the three main cargo types are Iron ore, coal, and wheat. The dataset consisted of monthly observations and covered the period between July 1999 and May 2018 for Capesize and Panamax markets and August 2005 and May 2018 for the Handymax market. Baltic Capesize Index (BCI), Baltic Panamax Index (BPI), and Baltic Handymax Index (BHI) were used to represent the freight markets for each type of vessel. After determining nonlinear structures in variables, asymmetric causality tests developed by (Hatemi-J, 2012) were applied to all markets, and some significant causal relationships were determined.

Firstly, when the Capesize market results were examined, significant causal relationships were determined from iron ore and wheat prices. Both positive and negative shocks in iron ore prices were identified as the cause of adverse shocks in Capesize freight levels. The authors revealed that damaging to adverse shocks may be explained by the decrease in the demand for iron ore, which consequently causes a decrease in its price. As the demand for maritime transport has a derived demand structure, the demand for Capesize ships reduces, and hence the freight rates fall. The authors explained favourable to adverse shocks by non-demand driven movements in iron ore prices. An increase in the iron ore prices may be caused by the producer countries' trade policies since there are few suppliers in the world. This increase in prices may hurt freight rates by negatively affecting the demand for ore. However, the authors stated that this situation needs empirical testing.

On the other hand, a significant causality relation was determined from the wheat, which is not generally preferred to be transported by Capesize vessel type. According to Chen et al. (2014), only 0\%$5 \%$ of the wheat cargo is transported by Capesize vessels worldwide. Adverse shocks in wheat prices were the causes of negative shocks in Capesize freight rates. The authors explained this as the decrease in wheat price may be caused by the decrease for this commodity, and available tonnage for wheat transport consisted of other types of the vessel may enter the Capesize market and cause an over-supply in the market. As the other types of vessels are common to Capesize cargoes, freight rates for Capes may be negatively affected. 
For the Panamax market, the causal impact of iron ore price was similar to the Capesize case, and the mechanism can be interpreted in the same way. When the wheat price is analysed, unlike in Capes, positive shocks in wheat price positively affect Panamax freight rates. The authors argued that demanddriven price increases in the wheat might positively affect the Panamax freight market since this increase may reflect the increase in demand for transportation activities. Lastly, according to the Handymax market results, there were significant causalities from iron ore and coal prices. The negative shock in the iron ore price is the cause of adverse shocks in the freight market. This result may be attributed to a demand-driven price decline in iron ore prices, as is the case in all other vessel types. While there was no causal impact from wheat price to the market, the only significant causality from coal price was included in the Handymax market. The positive shocks were the causes of the adverse shocks, and the negative shocks were the causes of positive shocks. The authors found this situation to be difficult to explain by demand-driven arguments. The situation was explained by the economies of scale, which was related to transport cost per unit. An increase in coal price may trigger searching for cheaper sources at longer distances; therefore, larger vessels may be used to obtain these sources thanks to the lower transport costs per unit. Demand for Handymax vessels may be negatively affected by this situation, which may consequently cause a fall in freight rates in the market. In the case of a decrease in the coal price, the opposite scenario may occur, and vessels' demand may increase. From the general perspective, it was concluded that commodity prices vary according to the type of commodity and the shipping market.

There are also indices used for the ships' freight levels carrying out their commercial activities in relatively narrow regions and indices formed by large markets. One of them is the ISTFIX index which is an essential indicator of the freight levels around Turkey and is used to track freight flows in the Black Sea and Mediterranean regions (Ünal and Köseoğlu, 2014). Although the market is relatively small, there will likely be an interaction between the cargo transported in the region and the freight levels. Based on this research question, we tested the effects of coal, steel, and wheat prices, which are primarily transported in the region, on the freight rates by implementing a unidirectional asymmetric causality test (Açık and Başer, 2020). As a result of the analyses that we applied considering the non-linearity in the series, significant causal relationships were found between the positive-positive shocks and the negative-negative shocks from the coal and steel prices to the freight index. However, the situation differs in wheat, and positive shocks in the commodity cause adverse shocks in the index, and negative shocks in the commodity cause positive shocks in the index. The results obtained are interpreted similarly for steel and coal; Increasing commodity prices in line with rising demand also increases the demand for sea transportation, causing freight and vice versa. For wheat, it can be considered a negative reflection of increasing prices, possibly due to supply cuts, the demand for wheat, and sea transportation. It can be said that the decreasing prices were realised due to the excess supply and thus the increase in the freight rates by increasing the demand for sea transportation. Unlike other commodities, the fact that the wheat is open to such unplanned irregularities with its climate-affected structure may support such findings.

In terms of information flow between commodity prices and freights, a study similar to our thesis was done by Angelopoulos et al. (2020). In their study, researchers studied the information pass-through between commodity prices and corresponding dry bulk and tanker freights. They used Time-Charter Equivalent versions of Baltic Capesize Index, Baltic Panamax Index, Baltic Supramax Index, Baltic Handysize Index, and the Baltic Dry Index (BDI) representatives of the dry bulk freight rates. As a result of the research, they found that commodity prices significantly affect the freight rates, but the interaction varies according to the dry bulk and tanker market. The increase in the prices of the cargoes in dry bulks causes an increase in the freight rates in the dry bulk market, while the increase in the prices of petroleum products causes a decrease in the tanker market. They also found that the price discovery mechanism is between the commodity and freight markets and the maritime markets' sub-components. In terms of dry bulk cargo, in general, they found that commodity prices are informationally leading to freight rates. 
When the studies examining the relationship between commodity prices and freights are examined, some studies determine significant relationships both from commodity price to freights and from freight to commodity prices. These relationships may differ according to the method, commodity type, and ship type.

\section{Commodity and Freight Derivative Markets}

In maritime markets, some markets are derived from the main markets in order to meet the demand. Stakeholders developed these markets to enable commercial activities to be maintained more easily. One of these is derivative markets, which are derived from freight markets. A derivative contract is the decision of a freight rate for the future with the two parties' agreement. Thus, the risks caused by large fluctuations in the freights are reduced (Stopford, 2009:193). This is because it is tough to predict, as freight markets can be affected by many factors. The future price may, of course, also deviate in favour of the shipowner or cargo owner. Since there are derivative markets in commodity prices, there is likely a flow of information between the freight and commodity derivative markets. Based on this research question, Kavussanos et al. (2010) examined the information flow between Panamax derivative markets and commodity derivatives markets. The commodity derivatives examined in the study consist of grain, iron ore, coal, bauxite, sulfur. In their analysis, researchers used GARCH, co-integration, VECM, and Granger causality analysis. As a result of their research, the authors concluded that the grain futures markets are an essential indicator for future freight markets. These findings are essential to reduce investors' risks of uncertainty in a risky market such as maritime. In another study, Kavussanos et al. (2014) expanded the subject a little more and made it cover the Capesize, Panamax, and Supramax markets, and the included commodity futures in the market were coal, corn, wheat, and soybeans. As a result of the study, it was concluded that the commodity derivatives markets in general are the pioneers in terms of return and volatility to the freight derivative markets. In terms of returns, the spillover from commodities to freights was determined for the Panamax and Supramax markets. However, no significant spillover was identified for the Capesize and coal derivatives markets. These results indicate a general flow of information from the commodity derivative markets to the freight derivative markets.

\section{Commodity and Second-hand Markets}

The effect of commodity prices on the freight market is crystal clear with the studies we have mentioned. This effect can be thought of as a direct effect. On the other hand, it is also likely that commodity prices will impact other maritime markets. Based on this research question, the effect of commodity prices on the ship sale and purchase market, which is the most active market after the freight market, was examined in a study by Başer and Açık (2019). The study examined the effect of iron ore price, which is the type of cargo most commonly carried by Capesize type vessels, on the values of 5-year-old Capesize vessels. Two hundred twenty-seven monthly observations covering the dates between July 1999 and May 2018 were used, and asymmetric causality analysis was applied in the study. The results revealed that positive shocks in iron ore price are the cause of positive shocks and the adverse shocks in the iron ore price are the cause of adverse shocks in the value of a 5-year-old vessel. This situation has been evaluated in two ways; first, when demand for commodities increases, freight rates increase as the demand for transport increases, and the value of their assets increases since this leads to an increase in future income levels for ship owners. Second, since iron ore is the raw material of steel, the increase in its price has led to an increase in shipbuilding costs, and the rise in second-hand ship prices has also occurred. The first one was described as a Demand-driven effect and the second one as a Cost-driven effect by the authors.

\section{Other Commodity Related Studies}

In a study carried out in order to determine the price bubbles in the dry bulk freight market through Baltic Dry Index and possible factors causing these price bubbles, we determined several events causing minor deviations from the actual price and categorised these events into the factors (Açık and Başer, 2018a). Firstly, the generalised sup augmented Dickey-Fuller (GSADF) test was determined using 1550 
daily data covering the January 2012 and May 2018 period. The presence of 8 price bubbles in different specifications was revealed. Then, the maritime market reports which correspond to these bubble periods were examined, and the events that occurred in those periods were investigated. As a conclusion of the study, the events were categorised into eight factors: climatic factors, cultural factors, political factors, voyage factors, operational factors, production factors, adjacent market factors, and sentiment factors. Contents of the factors can be exemplified as changes in sail routes due to storm, unavailability of service in ports due to cultural holiday holidays, trade embargoes among countries, long-distance charter contracts, miners' production increase decisions, cargo shift among different ship types and shipowners' festive atmospheres about the market.

The effect of commodity prices on the maritime freight markets in the short run through oil price and tanker market was investigated as a thesis (Açık, 2016) and then as an article (Açık and Başer, 2018b). The study's main focus was to examine the impact of the oil price, which was $\$ 120$ at the beginning of 2013 and decreased to $\$ 27$ in 2016, on the four-tanker market. The research's central hypothesis is that falling oil prices increase the oil demand, and this decrease positively affects tanker transportation in the short run due to the derived demand structure of the market. A period of 3 years was taken for the analysis because ship production lasts between 1-3 years. Due to this time-demanding nature of shipbuilding, its supply has an inelastic structure in the short run. This structure can cause considerable fluctuations in the market, and sudden increases in demand can lead to sudden increases in freight and, therefore, in the remaining maritime markets. Based on the correlation analysis, significant correlations were found between five maritime markets and crude oil prices. Accordingly, freight rates (Time Charter Rates), new building prices, second-hand ship values, and tanker companies' share values negatively correlate with oil prices, while demolition prices have a positive correlation.

\section{Methodology}

The causality in variance test, which is the primary method applied in the research, and its pre-tests are introduced in this section.

\section{Causality in Variance}

Granger (1969) developed the standard causality test to test the causality relationship between two-time series. The intuition of the test is as follows: if the historical data of one series helps to improve predicting the current and future values of the other series (Yu et al., 2015), the first series is expressed as the Granger cause of the second series (Dura et al., 2017). In the circumstances, the test detects a significant correlation between the historical values of the first series and the present value of the second series in the case of causality (Chiou-Wei, 2008). However, as mentioned in the previous sections, the time series may not always be linear. This situation makes it challenging to analyse with linear methods and brings non-linear methods to the fore. Causality in variance test is one of these non-linear methods, which is developed in order to investigate non-linear time series.

The causality in variance test, which is a current causality analysis and examines the causality relationship between the variables' variances, can provide essential findings, especially for the financial markets. The transmissions between financial markets can be tested and identified by this method (Koseoglu and Çevik, 2013) since it spots the volatility spillover between the two variables (Bayat et al., 2015). The variance changes when the new information arrives and reflects how this information is interpreted in the market (Cheung and $\mathrm{Ng}, 1996)$.

The fundamentals of the method were formed by Cheung and $\mathrm{Ng}$ (1996) for the first time, and the method was developed over time by overcoming the missing aspects. Squared univariate GARCH residuals estimates and their cross-correlation function (CCF) lie at the bottom of the method. However, when the volatility processes are leptokurtic, the corresponding CCF-based Portmanteau test statistics may be problematic in relatively small samples (Nouira et al., 2019). This situation reduced the method's applicability, and one of the methods developed to overcome this deficiency is the volatility spillover test based on the Lagrange Multiplier (LM) principle. The method was developed by Hafner and 
Herwartz (2006), and they proved the robustness of the LM approach towards spotted deficiencies by using Monte Carlo simulations (Nazlioglu et al., 2013).

The null of non-causality in the variance hypothesis between the two variables can be defined as follows;

$$
H_{0}: \operatorname{Var}\left(\varepsilon_{i t} \mid F_{t-1}^{(j)}\right)=\operatorname{Var}\left(\varepsilon_{i t} \mid F_{t-1}\right) \quad j=1, \ldots, N, i \neq j
$$

$F_{t}^{(j)}=F_{t} \backslash \sigma\left(\varepsilon_{j \tau}, \tau \leq t\right)$ and $\varepsilon_{i t}$ indicates the residuals from the estimated GARCH models. The model below is used to test the null hypothesis:

$$
\varepsilon_{i t}=\xi_{i t} \sqrt{\sigma_{i t}^{2} g_{t}}, g_{t}=1+z_{j t}^{\prime} \pi, \quad z_{j t}=\left(\varepsilon_{j t-1}^{2}, \sigma_{j t-1}^{2}\right)
$$

In order to test the volatility spillover between variables, the following LM test is recommended by Hafner and Herwartz (2006):

$$
\lambda_{L M}=\frac{1}{4 T}\left(\sum_{t=1}^{T}\left(\xi_{i t}^{2}-1\right) z_{j t}^{\prime}\right) V\left(\theta_{i}\right)^{-1}\left(\sum_{t=1}^{T}\left(\xi_{i t}^{2}-1\right) z_{j t}\right)
$$

where

$$
V\left(\theta_{i}\right)=\frac{\kappa}{4 T}\left(\sum_{t=1}^{T} z_{j t} z_{j t}^{\prime}-\sum_{t=1}^{T} z_{j t} x_{i t}^{\prime}\left(\sum_{t=1}^{T} x_{i t} x_{i t}^{\prime}\right)^{-1} \sum_{t=1}^{T} x_{i t} z_{j t}^{\prime}\right), \kappa=\frac{1}{T} \sum_{t=1}^{T}\left(\xi_{i t}^{2}-1\right)^{2}
$$

In this way, causality in the variance is tested between the series, and possible volatility spillovers are determined. The method used has some advantages and disadvantages in our research. First of all, this method tests mutual causality in variance between two variables, and a third or more variable cannot be included in the analysis, which can be seen as a disadvantage. Therefore, the freight rate and commodity prices are assumed to contain all the information available in their markets. As a result, all factors such as supply-demand imbalances, seasonal events, political balances, and cultural events are reflected in prices. The study of volatility spillover between the prices carrying this information makes the method reasonable and sufficient. It can be said that the method examines the relationship between the two variables through changes in the variance and eliminates the inadequacy caused by other external variables that are not considered. For whatever reason, the change in variance can cause a change in the other variable's variance. For example, whatever affects the commodity prices may be reflected in the prices, which may affect those interested in the related commodity. As a result, this impact may spill over to the commodity-related industries. Another advantage of the method is that it can be easily used by researchers whose theoretical background and coding skills are not very high. Since maritime economics is an application area rather than theoretical development, the convenience in the method's applicability provides a great advantage. Also, the method is considered to be an adequate one for research questions in our study. By testing the risk and volatility spillover between commodity prices and freight rates for each route, relevant results were obtained for the research questions.

\section{Unit Root}

In order to determine possible unit roots in time series, some tests should be applied. While some methods require stationarity (e.g. Linear Granger causality, causality in variance, DP causality), some methods need to know the degree of integration (e.g. Asymmetric causality, time-varying causality). Therefore, unit root tests are an essential step in any situation before the econometric analysis. In the series, structural breaks in level and trend caused by various reasons such as policy change, war, and 
crisis can lead to results as if the series has a unit root. Therefore, unit root tests, which also take into account breaks in the series, are of great importance to avoid misleading results.

Accordingly, one break ADF test developed by Zivot and Andrews (1992), one break LM test developed by Lee and Strazicich (2013), two break ADF test developed by Narayan and Popp (2010), two break LM test developed by Lee and Strazicich (2003) are applied to the series which take into account possible breaks in level and level and trend. GAUSS statistical software and codes are used in the analysis.

\section{Linearity}

In today's world, which is globalised, and the news is spreading rapidly, financial data is subject to many shocks and structural changes. This interaction causes the series to have high volatility and to be exposed to several crises, thus disrupting the series's linear structure (Bildirici and Turkmen, 2015). Besides, macro-scale factors such as reform policies, economic structure changes, investor heterogeneity, and fluctuations in industrial production cause deterioration in the series's linear structure (Ajmi et al., 2013). These events cause the variances to depend on time and distort the constant variance assumption (Månsson and Shukur, 2009). Conducting linear analyses in this kind of series may cause to obtain misleading results and may lead to unrealistic findings. Therefore, it is more appropriate to use the methods suitable to their structure by checking the series's linearity in question.

Brock (1991) used non-linear data and model to demonstrate that standard linear causality analysis fails to detect non-linear relationships when the issue is investigated through causality analysis. This deficiency is a natural result considering linear models' structures (Bal and Rath 2015; Adıgüzel et al., 2013). In order to test non-linearity in the series, BDS Independence (Brock et al., 1987), ARCH LM (Engle, 1982), and Ljung-Box (1978) tests are applied to the series.

BDS Independence test was designed by Brock, Dechert, and Scheinkman (1987). Before the implementation, a model is estimated (e.g., ARMA model), and the test is implemented to the residuals of the model to check whether the residuals are independent and identically distributed (i.i.d. assumption). The null hypothesis for this test indicates an iid assumption (Brock et al., 1996), and rejection of the hypothesis implies possibly non-linear structure in the series. LB portmanteau test was developed by Ljung-Box (1978), and it is generally implemented to the squared residuals of the estimated model (McLeod et al., 2012:683). The null hypothesis of the test can be evaluated as linearity, and therefore the rejection of the null hypothesis indicates non-linearity. The ARCH LM test developed by Engle (1982) is used to detect non-linearities, and its null hypothesis indicates linearity (Heij et al., 2004:628).

In this respect, when the null hypothesis is rejected in any of the mentioned non-linearity tests, the application of non-linear methods rather than linear ones may provide more reliable results (Lim and Ho, 2013).

\section{Data}

Commodity prices are obtained from the World Bank (2019). The freight information of the vessels is obtained from Bloomberg Data Platform (2019), and their monthly averages are obtained from weekly observations. Capesize dataset, presented in Table 2, covers the dates between January 2000 and June 2019. SALBE refers to the Capesize route from Saldanha (South Africa) to Beilun (China), TUBQINQ refers to the Capesize route from Tubarau (Brazil) to Qingdao (China), TUBROT refers to the Capesize route from Tubarau (Brazil) to Rotterdam (Netherlands). The units of these three routes are $\$$ per metric tons. 
Table 2. Descriptive Statistics for the Capesize Dataset

\begin{tabular}{|l|c|c|c|c|c|c|}
\hline & COAL & ORE & WHEAT & SALBE & TUBQINQ & TUBROT \\
\hline Mean & 69.76 & 83.46 & 195.53 & 17.61 & 23.55 & 12.34 \\
\hline Median & 67.51 & 69.55 & 187.81 & 13.40 & 19.31 & 9.11 \\
\hline Maximum & 180.00 & 197.12 & 419.61 & 77.02 & 97.51 & 53.53 \\
\hline Minimum & 22.25 & 28.79 & 90.87 & 4.07 & 5.53 & 2.75 \\
\hline Std. Dev. & 32.24 & 47.74 & 66.81 & 12.89 & 16.91 & 9.02 \\
\hline Skewness & 0.44 & 0.74 & 0.65 & 2.29 & 2.21 & 2.17 \\
\hline Kurtosis & 2.75 & 2.49 & 2.91 & 8.98 & 8.61 & 8.36 \\
\hline Jarque-Bera & 8.21 & 23.93 & 16.55 & 556.0 & 499.3 & 465.3 \\
\hline Probability & 0.01 & 0.00 & 0.00 & 0.00 & 0.00 & 0.00 \\
\hline Observations & 234 & 234 & 234 & 234 & 234 & 234 \\
\hline
\end{tabular}

Source: Worldbank, 2019; Bloomberg, 2019

Panamax dataset presented in Table 3 covers the dates between February 2001 and June 2019. HAMROT refers to Panamax route from Hampton Road (USA) to Rotterdam (Netherlands), RICROT refers to Panamax route from Richard Bay (South Africa) to Rotterdam (Netherlands), ROBROT refers to Panamax route from Roberts Bank (Canada) to Rotterdam (Netherlands), WAROT refers to Panamax route from South Wales to Rotterdam (Netherlands). The units of these three routes are \$ per metric tons.

Table 3. Descriptive Statistics for the Panamax Dataset

\begin{tabular}{|l|c|c|c|c|c|c|c|}
\hline & COAL & ORE & WHEAT & HAMROT & RICROT & ROBROT & WAROT \\
\hline Mean & 72.29 & 86.67 & 201.16 & 13.94 & 15.55 & 25.05 & 23.16 \\
\hline Median & 71.07 & 71.53 & 190.3 & 12.00 & 12.62 & 21.07 & 18.46 \\
\hline Maximum & 180.0 & 197.12 & 419.6 & 48.75 & 58.00 & 90.0 & 88.34 \\
\hline Minimum & 22.25 & 29.31 & 97.42 & 4.82 & 4.36 & 8.36 & 6.26 \\
\hline Std.Dev. & 31.37 & 47.19 & 64.44 & 7.87 & 9.59 & 13.77 & 14.13 \\
\hline Skewness & 0.41 & 0.69 & 0.70 & 1.93 & 1.86 & 1.83 & 1.78 \\
\hline Kurtosis & 2.86 & 2.43 & 2.97 & 7.23 & 6.95 & 7.14 & 6.76 \\
\hline Jarque-Bera & 6.63 & 20.90 & 18.05 & 302.7 & 272.0 & 282.4 & 247.9 \\
\hline Probability & 0.03 & 0.00 & 0.00 & 0.00 & 0.00 & 0.00 & 0.00 \\
\hline Observations & 221 & 221 & 221 & 221 & 221 & 221 & 221 \\
\hline
\end{tabular}

Source: Worldbank, 2019; Bloomberg, 2019

Handymax dataset, presented in Table 4, covers the dates between January 2009 and June 2019 and consists of 126 monthly observations. USJAP refers to the Handymax route from the US Gulf to Japan. PANSA refers to Handymax route from Pacific Northwest (US) to South America.

Table 4. Descriptive Statistics for the Handymax Dataset

\begin{tabular}{|l|c|c|c|c|c|}
\hline & COAL & ORE & WHEAT & PANSA & USJAP \\
\hline Mean & 86.47380 & 100.6030 & 227.4696 & 49.68036 & 46.66348 \\
\hline Median & 86.98000 & 88.83000 & 209.8247 & 49.84375 & 46.90000 \\
\hline Maximum & 132.4800 & 187.1800 & 346.4928 & 66.33333 & 72.85714 \\
\hline Minimum & 49.02000 & 40.50000 & 157.5605 & 42.34783 & 23.21739 \\
\hline Std.Dev. & 20.60809 & 39.48412 & 48.84567 & 5.671771 & 11.54198 \\
\hline Skewness & 0.127367 & 0.461457 & 0.674789 & 1.043974 & 0.005553 \\
\hline Kurtosis & 2.202819 & 1.963352 & 2.468203 & 3.746093 & 2.726485 \\
\hline Jarque-Bera & 3.677032 & 10.11365 & 11.04690 & 25.80996 & 0.393403 \\
\hline Probability & 0.159053 & 0.006366 & 0.003992 & 0.000002 & 0.821436 \\
\hline Observations & 126 & 126 & 126 & 126 & 126 \\
\hline
\end{tabular}

Source: Worldbank, 2019; Bloomberg, 2019

\section{Results and Discussion}

Since the stationarity of the data is required for causality analysis, unit root tests are applied. Besides, the series's non-linear structures are tested to be able to apply non-linear causality analysis. Unit root tests with structural breaks were applied to each variable to determine the possible unit root conditions in the variables, and these results were presented in Appendix 1. The results revealed that all the data 
used were stationary when the series's structural breaks were taken into account. Structural break dates of the relevant series were also presented in the appendix. The break dates in the unit root tests with structural break reveal the 2008 global economic crisis's effects. Structural breaks in freight rates were generally observed towards the end of 2008, while breaks in commodity prices were observed towards 2007. This situation can be evaluated as the crisis effect was first felt in commodity prices and then spread to the freight market. Because maritime markets have a derived demand structure, demand for commodities has affected the demand for shipping. Due to a possible decrease in demand, the break-in commodity prices were reflected in the maritime market with a short delay. There have been breaks in both levels and trends in freight rates. After that, freight rates have followed a trend far from their previous high levels. The main factor is that many new ships are ordered during the economic boom period, and demand growth remains relatively slow.

BDS non-linearity tests were applied to residuals after estimating the most suitable ARMA model for each series by lowest AIC values, and the results were presented in Appendix 2. According to the results, the linearity null hypothesis could not be rejected in wheat prices in all markets. However, the linearity null hypothesis was rejected for all other variables in all samples. The linearity null hypothesis was rejected with some lags in the Capesize and Panamax samples with the ARCH LM test in terms of wheat price. On the Handymax market, the hypothesis could not be rejected as the data is partially short. However, because of the non-linearity in long data sets of the wheat price, the wheat price in the Handymax sample was considered non-linear, and the analyses were applied.

The results of the causality in variance test applied for the Capesize market are presented in Table 5. In the ore price case, the results show that there are significant causal relationships from the iron ore price to the SALBE, TUBQINQ, and TUBROT cargo routes. There are significant causal relationships from the coal price to all the coal price cases' routes. The results obtained for the wheat commodity differ considerably from other results. The bidirectional null of the non-causality hypothesis is rejected for all routes. In other words, for the commodity as mentioned above, there are causality relations both from the commodity to freight rates and from freight rates to commodity.

Table 5. Causality Results of Capesize Freights

\begin{tabular}{|c|c|c|}
\hline Causality-in-variance from & LM stat & p-value \\
\hline ORE to SALBE & 8.689 & $0.0130^{* *}$ \\
\hline SALBE to ORE & 1.761 & 0.4145 \\
\hline ORE to TUBQINQ & 9.231 & $0.0099^{* * *}$ \\
\hline TUBQINQ to ORE & 0.761 & 0.6834 \\
\hline ORE to TUBROT & 8.064 & $0.0177^{* *}$ \\
\hline TUBROT to ORE & 2.105 & 0.3491 \\
\hline COAL to SALBE & 6.093 & $0.0475^{* *}$ \\
\hline SALBE to COAL & 0.397 & 0.8200 \\
\hline COAL to TUBQINQ & 5.779 & $0.0556^{*}$ \\
\hline TUBQINQ to COAL & 0.412 & 0.8138 \\
\hline COAL to TUBROT & 5.885 & $0.0527^{*}$ \\
\hline TUBROT to COAL & 0.428 & 0.8074 \\
\hline WHEAT to SALBE & 5.155 & $0.0760^{*}$ \\
\hline SALBE to WHEAT & 6.682 & $0.0354^{* *}$ \\
\hline WHEAT to TUBQINQ & 5.851 & $0.0536^{*}$ \\
\hline TUBQINQ to WHEAT & 5.906 & $0.0522^{*}$ \\
\hline WHEAT to TUBROT & 8.896 & $0.0117^{* *}$ \\
\hline TUBROT to WHEAT & 7.356 & $0.0253^{* *}$ \\
\hline
\end{tabular}

Note: $\mathrm{H}^{0}$ rejected ${ }^{* * *} 1 \%,{ }^{* *} 5 \%,{ }^{*} 10 \%$.

The results of the Panamax freight market were presented in Table 6. For the iron ore price, the null of non-causality hypothesis can be rejected for only two routes. There are significant causal relationships from the Iron ore price to the freights on the HAMROT and RICROT routes. The significant causalities from commodity price to freight route were determined only for the same routes for the coal price. For the wheat price, significant causal relationships were determined for all routes. In HAMROT and 
RICROT routes, the relationship is bidirectional, and in ROBROT and WAROT routes, the relationships are from freight routes to wheat price.

Table 6. Causality Results of Panamax Freights

\begin{tabular}{|c|c|c|}
\hline Causality-in-variance from & LM stat & p-value \\
\hline ORE to HAMROT & 5.192 & $0.0746^{*}$ \\
\hline HAMROT to ORE & 0.445 & 0.8004 \\
\hline ORE to RICROT & 5.453 & $0.0655^{*}$ \\
\hline RICROT to ORE & 0.900 & 0.6375 \\
\hline ORE to ROBROT & 2.293 & 0.3177 \\
\hline ROBROT to ORE & 0.283 & 0.8679 \\
\hline ORE to WAROT & 3.384 & 0.1841 \\
\hline WAROT to ORE & 0.477 & 0.7877 \\
\hline COAL to HAMROT & 9.739 & $0.0077^{* * *}$ \\
\hline HAMROT to COAL & 0.363 & 0.8339 \\
\hline COAL to RICROT & 6.632 & $0.0363^{\text {** }}$ \\
\hline RICROT to COAL & 1.563 & 0.4578 \\
\hline COAL to ROBROT & 2.717 & 0.2571 \\
\hline ROBROT to COAL & 2.344 & 0.3097 \\
\hline COAL to WAROT & 3.521 & 0.1719 \\
\hline WAROT to COAL & 2.964 & 0.2272 \\
\hline WHEAT to HAMROT & 6.720 & $0.0347^{\text {** }}$ \\
\hline HAMROT to WHEAT & 5.620 & $0.0602^{*}$ \\
\hline WHEAT to RICROT & 5.829 & $0.0542^{*}$ \\
\hline RICROT to WHEAT & 7.983 & $0.0185^{* *}$ \\
\hline WHEAT to ROBROT & 2.604 & 0.2720 \\
\hline ROBROT to WHEAT & 6.826 & $0.0329^{* *}$ \\
\hline WHEAT to WAROT & 3.989 & 0.1361 \\
\hline WAROT to WHEAT & 10.836 & $0.0044^{* * *}$ \\
\hline
\end{tabular}

Note: $\mathrm{H}^{0}$ rejected ${ }^{* * *} 1 \%,{ }^{*} 5 \%,{ }^{*} 10 \%$.

The results of the Handymax market were presented in Table 7. The null of the non-causality hypothesis could not be rejected on either route for the iron ore price. For the coal price, the null of non-causality hypothesis can be rejected for one route. There is a significant causal relationship between the USJAP route to coal price. For the wheat price, there is one causal relationship from the PANSA route to wheat price.

Table 7. Causality Results of Handymax Freights

\begin{tabular}{|c|c|c|}
\hline Causality-in-variance from & LM stat & p-value \\
\hline ORE to PANSA & 2.787 & 0.2481 \\
\hline PANSA to ORE & 4.314 & 0.1157 \\
\hline ORE to USJAP & 0.754 & 0.6861 \\
\hline USJAP to ORE & 4.507 & 0.1050 \\
\hline COAL to PANSA & 2.868 & 0.2384 \\
\hline PANSA to COAL & 3.892 & 0.1429 \\
\hline COAL to USJAP & 1.978 & 0.3719 \\
\hline USJAP to COAL & 9.696 & $0.0078^{\star \star *}$ \\
\hline WHEAT to PANSA & 2.113 & 0.3477 \\
\hline PANSA to WHEAT & 7.683 & $0.0215^{\star *}$ \\
\hline WHEAT to USJAP & 0.591 & 0.7441 \\
\hline USJAP to WHEAT & 0.273 & 0.8723 \\
\hline
\end{tabular}

Note: $\mathrm{H}^{0}$ rejected ${ }^{* *} 1 \%,{ }^{* *} 5 \%,{ }^{*} 10 \%$.

According to Cheung and $\mathrm{Ng}$ (1996), changes in a variable's variance relate to how new information is received and evaluated. In this context, it can be said that supply-demand information is transferred from commodity prices to freights. Price changes in the commodities carry this information, as commodities' prices mainly affect the demand for them or their supply or are affected by these factors. 
For instance, price increase due to the increase in demand may positively reflect the maritime freight markets, while price increase due to the supply interruption may negatively reflect the market. All this information is reflected primarily on the price of the commodity and then on the freight levels.

When we evaluate the causality in variance test results in general, it can be stated that a result like Table 8 appears. There is a causal relationship between iron ore and coal prices to all Capesize freight routes in the sample. When looking at the wheat commodity situation, there is a causality relationship from wheat price to all routes and from all wheat price routes. Results obtained for the Panamax market show similar characteristics to the Capesize market. A significant causal relationship was obtained from iron ore and coal prices to two of the four routes in the sample: HAMROT (Hampthon Road - USA to Rotterdam - Netherlands) and RICROT (Richard Bay South Africa to Rotterdam - Netherlands). When the wheat relations were examined, a significant causality relationship was determined from wheat prices to all routes, while a significant relationship was determined from wheat prices to two routes, which are again HAMROT and RICROT. For Handymax, significant relationships detected are relatively more minor. While a significant causal relationship with ore price could not be spotted, causality relationships were determined from the USJAP route to coal price and the PANSA route to wheat price.

Table 8. General Results According to the Freight Market

\begin{tabular}{|l|c|c|}
\hline Commodity Price & Causality Direction & Freight Market \\
\hline Iron Ore & $\rightarrow$ & Capesize \\
\hline Coal & $\rightarrow$ & Capesize \\
\hline Wheat & $\leftrightarrow$ & Capesize \\
\hline Iron Ore & $\rightarrow$ & Panamax \\
\hline Coal & $\rightarrow$ & Panamax \\
\hline Wheat & $\leftrightarrow$ & Panamax \\
\hline Iron Ore & $\mathrm{X}$ & Handymax \\
\hline Coal & $\leftarrow$ & Handymax \\
\hline Wheat & $\leftarrow$ & Handymax \\
\hline
\end{tabular}

Considering that Capesize type ships are specialised in iron ore cargoes and according to Chen et al. (2014), 70-80\% of the total iron ore cargo is carried by this type of ships, it is inevitable that any situation related to iron ore will affect this market. Price changes in iron ore spillover to Capesize freights. In other words, the variance of the ore price affects the variance of the freights by generating a flow of information. Although iron ore is laboriously transported by Capesize-type ships, ore price on the Panamax-type ships may be due to the neighbouring market impact, as we have reviewed while examining the industry reports. Capesize traffic intensifies when iron ore demand increases excessively, and increased freight may cause Panamax type vessels to enter the iron ore market. Although transportation costs per unit are not as low as Capesize ships, they can still profit after a certain freight level in the iron ore transportation.

There is a causal relationship between the iron ore price and the coal price to the Capesize and Panamax market routes related to the intensive use of these products in the industrial area. The general areas of iron ore are construction, infrastructure, automotive, white goods, and machinery industries. In contrast, the general coal use areas are power generation, steel, cement production, coal liquefaction, and household consumption, which are essential for national economies and household welfare. For all these reasons, the demands of these commodities may not be affected by the transportation costs, and therefore a significant causal relationship from freight rates to commodities may not be detected in Capesize and Panamax markets. In contrast to these markets, in the Handymax market, a significant causality relationship was determined from the freight route to the commodity price. This result may be related to the transportation costs of ship types per unit. For example, the average shipping freight per ton on routes included in the study are $\$ 17.83$ for Capesize routes, $\$ 19.25$ for Panamax routes, and $\$ 48.17$ for Handymax routes. Although the rate of coal transportation by Handymax type ship is 
relatively low, the price of coal tends to respond according to the information flow in the Handymax freight routes as the average transportation cost is high compared to the coal price market. The absence of any significant relationship between Handymax freights, and iron ore price is probably due to this vessel type's infrequent use in iron ore transportation. They are used in inland waters and ports where large ships cannot berth due to physical conditions. Freight owners are, therefore, willing to pay high transportation costs per unit.

This situation in iron ore and coal may also be due to the market structure. In some sources, the iron ore market is defined as an oligopolistic industry since it is concentrated on a few producers (Johnson et al., 2014:46), and these producers can influence the prices (Bullock and Mernitz, 2017:220). Also, the coal market is generally defined as an oligopolistic market since the coal product is relatively homogenous (Schernikau, 2016:448) and the small number of firms carry out production activities (Mosk, 2008:14). In this context, due to companies that have the power to influence the prices of these commodities, the information flow may have occurred from commodity prices to freights. Besides, according to the BDS test results, these two markets could not be determined as efficient in the weak form, and it was demonstrated that the prices are dependent on the historical values and can be estimated.

The situation differs partially for wheat commodity. While there are one-way relations of freight routes with other cargo types, there are routes with two-way relations with wheat. This result may be due to the structure of the wheat market or its close relationship with oil. Since the market is defined as a perfectly competitive market, the producers in the world are price takers (Fisher and Waschik, 2002:23), the products are generally homogenous, and there are no entry barriers to the industry (Ragan, 2014:203). As there are many companies in this respect, they may adjust the price according to the freights' information to maintain commercial activities in the market.

Grains can be used extensively in biofuel production, depending on the situation in oil prices. As production costs are relatively high, they are affected by volatility in oil prices. This situation has been confirmed by many studies in the literature (Alghalith, 2010; Alom et al., 2011; Nazlıoglu et al., 2013). In this context, a volatility spillover from freight to wheat price may have been achieved since ships' most important voyage costs are fuel costs, and freight is affected by volatilities in this commodity.

Another finding for the wheat commodity is the findings related to the Efficient Market Hypothesis's validity $(\mathrm{EMH})$ in the weak form, although it is not within this study's scope. BDS Independence test has been used in many studies (Blasco et al., 1997; Afonso and Teixeira, 1998; Dorina and Simina, 2007; Lim and Brooks, 2011; Bhattarai and Margariti, 2018) to measure market efficiency before. In this study, the method we use for testing non-linearity also provides information about the markets' structures since it tests whether there are possible hidden dependencies between the values through time. In this respect, the BDS test's null hypothesis could not be rejected in the tests performed for all three ship-type samples for wheat price. This situation shows that the wheat price is efficient and moves randomly. In other words, tomorrow's price is independent of today's, and future prices cannot be estimated using the information in the historical data. This result can be explained by the fact that wheat depends on seasonal conditions, and there are many irregularities in its production. In this respect, since wheat is a difficult commodity to maintain and store compared to other industrial products (iron ore and coal), it may be affected by freight volatility due to commercial concerns regarding export activities. Generally speaking, the most logical situation about wheat is that it is affected by freight volatility due to its close relationship with the oil price.

The finding related to Capesize and ore price relationship also accords with the results of the studies conducted by Tsioumas and Papadimitriou (2018), Açı and İnce (2019), and Açık and Başer (2019), which reveals that iron ore price movements are helpful in the Capesize freight market. The finding regarding the coal and Capesize relationship is determined in the study conducted by Tsioumas and Papadimitriou (2018). The impact of ore price and coal on the Panamax market is empirically found in Açık and İnce (2019). Besides, while the only study in the literature containing analysis related to these researchers' Handymax market, it was determined that iron ore and coal prices were useful in 
Handymax freights. In contrast, the causal relationships were determined from freight rates to commodity prices in our results. Finally, in the study conducted by Tsioumas and Papadimitriou (2018) on the Panamax market, the causality relationship was determined from wheat price to Panamax freight in a similar way to us.

\section{Conclusion}

In general, we determined significant causality in variance relationships from some cargoes to some routes. These relationships can be interpreted as information flow and spread. Commodity prices, which are shaped by factors such as production costs, supply-demand balance, natural events, and market expectations, carry this information and transfer it to the maritime market, which has a derived demand structure. Whether positive or negative, volatility in prices spillovers to the freight markets, and the commodity market risk is transferred to the freight market. In this context, price discovery in freights is shaped according to the information carried by commodity prices. The high risk in commodity prices causes high risks in the freight market. Within the framework of the research questions, it has been determined that the information flow may differ according to the commodity type, and there is no only information flow to the freight of the ships from which the cargoes are transported intensively. There are also spillovers to other kinds of ships. Besides, in our study, we have determined the effects of the 2008 global economic crisis on both the maritime market and the commodity market with structural break tests. The crisis caused breaks in trends and levels in both markets. Also, since the ship orders placed before 2008 were included in the market after the crisis, there was too much ship supply, and this surplus could not be eliminated even yet. Recent political and economic crises have also contributed to this depressed course of the maritime markets. Countries with heavy debt negatively affect the demand for maritime transport since it has a derived demand structure. The increase in demand required to eliminate the excess supply in the market cannot be achieved. Besides, China's policy of securing transport supply by establishing its fleet, which was hurt by high freight rates before 2008, contributes to the constant high amount of supply in the market.

This study differs from the studies in the literature in two different ways. Firstly, some studies tried to derive results by using general freight indices in their analysis. However, depending on the weights of the indices' variables, different ships and routes can direct the index by pulling up or down other variables. In this study, we applied our analyses on individual routes of each ship type. We then tried to achieve generalisable results through these individual results.

Secondly, no study examining the flow of information due to the change in variance at current prices has been encountered. Derivative markets may lack an understanding of the relationship between variables, as conditions at that time in the future are uncertain. However, it is still crucial for the current studies to show the leading indicator situation and the information flow between them so that the ship owners can make their decisions more positively. Our study aims to examine the information flow and spillover between commodity prices and freights based on the events that have taken place. In this respect, it can be said that understanding the past mechanism is vital for understanding possible future relationships.

The maritime market is a high-risk market by nature. In this respect, ship owners need to reduce the risks arising from uncertainty to carry out sustainable commercial activities. As a result of our research for three major ship types subject to our study, we examined their relationship with three major dry bulk cargoes. Shipowners or charterers who operate such ships and carry out their commercial activities can benefit from our findings in the cargo they target. For example, the risks in iron ore and coal cargoes spillover to the freight of Capesize and Panamax vessels, while Handymax vessels are not affected by these risk transfers. Accordingly, people who will charter their ships for an extended period may choose customers based on the shippers' commercial philosophies and prefer risk-free cargo markets. Besides, Capesize and Panamax shipowners should follow the production and demand factors in the iron ore and coal commodity markets and consider the impact of changes in these factors on price volatility. Because volatility in commodity prices spillovers to freight rates and affects the risk. In this respect, 
these ship owners can plan their commercial strategies by considering their shipping cycles. For example, if they have high-risk expectations, they can choose the long-term time charter method. Alternatively, if they think the risk is temporary, they can continue their commercial activities in the spot market. Because the maritime market involves high risk and too many players, leading indicators are essential for making pro-active decisions. Since ships are significant investments that require much capital to purchase and operate, wrong decisions taken at the wrong time can lead to irreparable losses for years. In this study, we tried to reduce the risks arising from uncertainty by presenting ship-based leading indicators.

Some limitations of the study posed obstacles to more comprehensive analysis. The first one is the freight information for three routes for the Capesize market and only two routes for the Handymax market. For the Panamax market, carrying out the analyses with information about four routes has made it possible to obtain more complete results. A second constraint is that the route information obtained for Handymax type ships includes freights after 2009. More generalisable results would have been possible with a more comprehensive data set.

In subsequent studies, information and risk transfer trends in different periods can be examined by considering the data set breaks. For example, the 2008 economic crisis is a significant breaking point for both the world economy and the shipping market. As a result of unit root tests that take into account the breaks we have done, significant breaks were detected in the 2008 period. This finding is an important research question to examine before and after the crisis, as we conducted in a study (Açık and Başer, 2019) by a different method.

\section{Peer-review:}

Externally peer-reviewed

\section{Conflict of interests:}

The author(s) has (have) no conflict of interest to declare.

\section{Grant Support:}

The authors declared that this study has received no financial support

\section{References}

Açık, A. (2016). The effects of fast decline in crude oil prices on the tanker market in the short run, Dokuz Eylül University, Institute of Social Sciences, Master Thesis, İzmir.

Açık, A. \& Başer, S.Ö. (2018a). An analytical study on the likely causes of the minor bubbles in the Baltic dry index. International Journal of Logistics Economics and Globalisation, 7(4), 353-365.

Açık, A. \& Başer, S.Ö. (2018b). The effects of fast decline in crude oil prices on the tanker market in the short run. Dokuz Eylül Üniversitesi Denizcilik Fakültesi Dergisi, 10(1), 61-82.

Açık, A. \& Başer, S.Ö. (2019). Impact of Commodity Price on Freight Market Considering The 2008 Crisis: An Investigation of Iron Ore Price and Capesize Shipping Rates. II. Business \& Organisation Research Conference Full Text Book (pp. 1087-1099), Organised by Yaşar University. İzmir. 4th-6th September 2019.

Açık, A. \& Başer, S.Ö. (2020). Asymmetric causality from commodity prices to shipping markets: an empirical research on Istfix region. World Review of Intermodal Transportation Research, 9(1), 47-62.

Açı, A. \& İnce, M.R. (2019). Do commodity price shocks matter for dry bulk freight markets?. In Kaya, Ö. (Ed.), Studies on social sciences (pp. 77-101). Ankara: İKSAD Publishing House. 
Adıgüzel, U., Bayat, T., Kayhan, S. \& Nazlıŏlu, Ş. (2013). Oil prices and exchange rates in Brazil, India and Turkey: Time and frequency domain causality analysis. Siyaset, Ekonomi ve Yönetim Araştırmalar Dergisi, 1(1), 49-73.

Afonso, A. \& Teixeira, J. (1999). Non-linear tests of weakly efficient markets: Evidence from Portugal, ISEG Economics Department Working Paper, 6(98).

Ajmi, A. N. El Montasser, G. \& Nguyen, D. K. (2013). Testing the relationships between energy consumption and income in G7 countries with non-linear causality tests. Economic Modelling, 35, 126133.

Alghalith, M. (2010). The interaction between food prices and oil prices. Energy Economics, 32, 15201522.

Alizadeh, A. \& Nomikos, N. (2009). Shipping derivatives and risk management. London: Macmillian.

Alom, F., Ward, B. \& Baiding, H. (2011). Spillover Effects of World Oil Prices on Food Prices: Evidence from Asia and Pacific Countries. 52nd New Zealand Association of Economists Annual Conference. Wellington, New Zealand. 29th June-1st July 2011.

Angelopoulos, J., Sahoo, S. \& Visvikis, I. D. (2020). Commodity and transportation economic market interactions revisited: New evidence from a dynamic factor model. Transportation Research Part E: Logistics and Transportation Review, 133, 1-15.

Bal, D. P., \& Rath, B. N. (2015). Non-linear causality between crude oil price and exchange rate: A comparative study of China and India. Energy Economics, 51, 149-156.

Başer, S.Ö., \& Açık, A. (2019). Do commodity prices matter for second hand values? An empirical research on Capesize market. Turkish Journal of Maritime and Marine Sciences, 5(1), 44-52.

Başer, S.Ö., \& Açık, A. (2018). The response of shipbuilding activities to freight rates. Uluslararası İktisadi ve İdari Bilimler Dergisi, 4(1), 120-136.

Bayat, T., Nazlioglu, S., \& Kayhan, S. (2015). Exchange rate and oil price interactions in transition economies: Czech Republic, Hungary and Poland. Panoeconomicus, 62(3), 267-285.

Bendall, H., \& Stent, A.F. (2005). Investment strategies in market uncertainty. In Leggate, H. et al (Eds.), International maritime transport: Perspectives (pp. 13-23). London: Routledge.

Bhattarai, K., \& Margariti, V. (2018). An empirical test of the theory of efficient markets of stock prices. Finance and Market, 3(2), 1-30.

Bildirici, M. E., \& Turkmen, C. (2015). Non-linear causality between oil and precious metals. Resources Policy, 46, 202-211.

Blasco, N., Del Rio, C., \& Santamaría, R. (1997). The random walk hypothesis in the spanish stock market: 1980-1992. Journal of Business Finance \& Accounting, 24(5), 667-684.

Bloomberg. (2019, July 20). Freight rate data [Data provider]. Retrieved from https://www.bloomberg.com/professional/

Brock, W. (1991). Causality, chaos, explanation and prediction in economics and finance. In Casti, J.L., and Karlqvist, A. (Eds.), Beyond belief: Randomness, prediction and explanation in science (pp. 230-279). Boca Raton: CRC Press.

Brock, W., Dechect, W. \& Scheinkman, J. (1987). A test for independence based on the correlation dimension. Working Paper. Department of Economics, University of Wisconsin, Madison.

Brock, W., Dechert, D., Sheinkman, J. \& LeBaron, B. (1996). A test for independence based on the correlation dimension. Econometric Reviews, 15(3), 197-235.

Bullock R.L. \& Mernitz, S. (2017). Mineral property evaluation: Handbook for feasibility studies and due diligence. USA: Society for Mining, Metallurgy, and Exploration.

Chen, S., Meersman, H., Van de Voorde, E. \& Frouws, K. (2014). Modelling and forecasting in dry bulk shipping. Informa Law from Routledge.

Cheung, Y. W. \& Ng, L. K. (1996). A causality-in-variance test and its application to financial market prices. Journal of Econometrics, 72(1-2), 33-48.

Chiou-Wei, S. Z., Chen, C. F. \& Zhu, Z. (2008). Economic growth and energy consumption revisitedEvidence from linear and non-linear Granger causality. Energy Economics, 30(6), 3063-3076. 
Chou, M. T., Su, Y. L., Chou, T. Y. \& Liang, H. U. (2015). An analysis of the relationship between Asian Steel Index and the Baltic Capsize Index. Modern Economy, 6(2), 207-216.

Dorina, L. \& Simina, U. (2007). Testing efficiency of the stock market in emerging economies. The Journal of the Faculty of Economics-Economic Science Series, 2, 827-831.

Dura, Y. C., Beser, M. K. \& Acaroglu, H. (2017). Econometric analysis of Turkey's export-led growth. Ege Akademik Bakis, 17(2), 295-310.

ECMT. (2001). Short sea shipping in Europe. France: OECD Publications Service.

Engle, R. F. (1982). Autoregressive conditional heteroscedasticity with estimates of the variance of United Kingdom inflation. Econometrica: Journal of the Econometric Society, 50(4), 987-1007.

Fisher, T. \& Waschik, R. (2002). Managerial economics: A game theoretic approach. New York: Routledge.

Granger, C. W. (1969). Investigating causal relations by econometric models and cross-spectral methods. Econometrica: Journal of the Econometric Society, 37(3), 424-438.

Hafner, C. M. \& Herwartz, H. (2006). A lagrange multiplier test for causality in variance. Economics Letters, 93(1), 137-141.

Harlaftis, G. \& Theotokas, J. (2002). Maritime business during the 20th century: continuity and changes. In Grammenos, C. (Eds.), The handbook of maritime economics and business (pp. 3-34). London: Lloyd's of London Press.

Hatemi-J, A. (2012). Asymmetric causality tests with an application. Empirical Economics, 43(1), 447-456.

Heij, C., de Boer, P., Franses, P. H., Kloek, T. \& van Dijk, H. K. (2004). Econometric methods with applications in business and economics. New York: Oxford University Press.

Johnson, G., Whittington, R., Scholes, K., Angwin, D. \& Regnér, P. (2014). Exploring strategy. Italy: Pearson Education Limited.

Kavussanos, M., Visvikis, I. \& Dimitrakopoulos, D. (2010). Information linkages between panamax freight derivatives and commodity derivatives markets. Maritime Economics and Logistics, 12(1), 91110.

Kavussanos, M.G., Visvikis, I.D. \& Dimitrakopoulos, D.N. (2014). Economic spillovers between related derivatives markets: The case of commodity and freight markets. Transportation Research Part E, 68, 79-102.

Koseoglu, S. D. \& Cevik, E. I. (2013). Testing for causality in mean and variance between the stock market and the foreign exchange market: An application to The Major Central and Eastern European Countries. Finance a Uver, 63(1), 65-86.

Lee, J. \& Strazicich, M. C. (2003). Minimum Lagrange Multiplier unit root test with two structural breaks. The Review of Economics and Statistics, 85(4), 1082-1089.

Lee, J. \& Strazicich, M. C. (2013). Minimum LM unit root test with one structural break. Economics Bulletin, 33(4), 2483-2492.

Lim, K. P. \& Brooks, R. (2011). The evolution of stock market efficiency over time: A survey of the empirical literature. Journal of Economic Surveys, 25(1), 69-108.

Lim, S. Y. \& Ho, C. M. (2013). Non-linearity in ASEAN-5 export-led growth model: Empirical evidence from nonparametric approach. Economic Modelling, 32, 136-145.

Ljung, G. M. \& Box, G. E. (1978). On a measure of lack of fit in time series models. Biometrika, 65(2), 297303.

Månsson, K. \& Shukur, G. (2009). Granger causality test in the presence of spillover effects. Communications in Statistics-Simulation and Computation, 38(10), 2039-2059.

McLeod, A. I., Yu, H. \& Mahdi E. (2012). Time series analysis with R. In Rao, T. et al (Eds.), Time series analysis: Methods and applications (Vol. 30) (pp. 661-712). Elsevier.

Mosk, C. (2008). Japanese economic development: Markets, norms, structures. New York: Routledge.

Narayan, P. K. \& Popp, S. (2010). A new unit root test with two structural breaks in level and slope at unknown time. Journal of Applied Statistics, 37(9), 1425-1438. 
Nazlioglu, S., Erdem, C. \& Soytas, U. (2013). Volatility spillover between oil and agricultural commodity markets. Energy Economics, 36, 658-665.

Nouira R., Amor T.H. \& Rault C. (2019). Oil price fluctuations and exchange rate dynamics in the MENA Region: Evidence from non-causality-in-variance and asymmetric non-causality tests. Quarterly Review of Economics and Finance, 73, 159-171.

Ragan, C.T.S (2014). Microeconomics. Canada: Pearson.

Schernikau, L. (2016). Economics of the international coal trade: why coal continues to power the World. London: Springer.

Stopford, M. (2009). Maritime economics. London and New York: Routledge.

Tsioumas, V. \& Papadimitriou, S. (2018). The dynamic relationship between freight markets and commodity prices revealed. Maritime Economics and Logistics, 20(2), 267-279.

Ünal, G., \& Derindere Köseoğlu, S. (2014). Revealing the freight market risk in ISTFIX shipping area. International Journal of Shipping and Transport Logistics, 6(6), 593-610.

UNCTAD (2019, December 10). Merchant fleet by flag of registration and by type of ship [Data provider]. Retrieved from https:// unctadstat.unctad.org/wds/TableViewer/tableView.aspx?ReportId=93

WorldBank. (2019, December 28). Monthly commodity prices. https://www.worldbank.org/en/research/commoditymarkets

Yu, L., Li, J., Tang, L. \& Wang, S. (2015). Linear and non-linear Granger causality investigation between carbon market and crude oil market: A multi-scale approach. Energy Economics, 51, 300-311.

Zivot, E. \& Andrews, D. W. K. (2002). Further evidence on the great crash, the oil-price shock, and the unit-root hypothesis. Journal of Business \& Economic Statistics, 20(1), 25-44. 